\title{
Four Unique Pottery Vessels from N 2000 and $\mathrm{N} 2500$
}

\author{
Natasha D. Ayers
}

Among the largely homogeneous pottery corpus of typical First Intermediate Period and early Middle Kingdom funerary types from cemeteries N 2000 and $\mathrm{N} 2500$ are four vessels that necessitate further discussion for their singularity in The Phoebe A. Hearst Museum of Anthropology corpus and for their connection to wider trends for the period. ${ }^{1}$ A small carinated jar with partially blackened surface, a carinated bowl with white painted decoration, an offering stand with incised decoration, and a carinated bowl with spout are discussed separately below. ${ }^{2}$ Each pot receives a brief summary of the archaeological context, a description of the vessel, and a discussion with inclusion of parallel comparanda.

PAH MA 6-12510 Carinated Jar with Partially Blackened Surface

\subsection{Context}

This small carinated jar from burial N 2701 (Fig. 3.1) was part of an assemblage with cylindrical beakers with round bases known from mid-Dynasty 11 to early Dynasty $12,{ }^{3}$ a small "saucer," ${ }^{4}$ a piece of a ring stand, and, according to Hearst Museum records, two flint knives. ${ }^{5}$

1 Museum collections and excavation tomb cards from early twentieth-century excavations are rarely a complete record of every object that was excavated. A selection of pottery, usually complete vessels, was documented and retained. Sherds were usually discarded. This means the possibility of additional examples cannot be discounted, and "singularity" is used with this caveat.

2 All descriptions are based on original excavators' notes from the field (See Chapter 12), excavation negatives in the collection of the Hearst Museum, object photographs taken recently by Hearst Museum staff (available at: https://portal.hearstmuseum.berkeley.edu/), and Gabriella diBattista's drawings and descriptions of ceramics (Chapter 2) in the Hearst Museum. I did not view the pottery in the museum.

3 Cylindrical beaker PAнма 6-12509. Schiestl and Seiler 2012, 448.

4 No further description is given for the saucer.

5 PAHMA 6-12511; PAHMA 6-12513.

(C) NATASHA D. AYERS, 2021 | DOI:10.1163/9789004396906_005

This is an open access chapter distributed under the terms of the CC BY-NC-ND Aat license. 

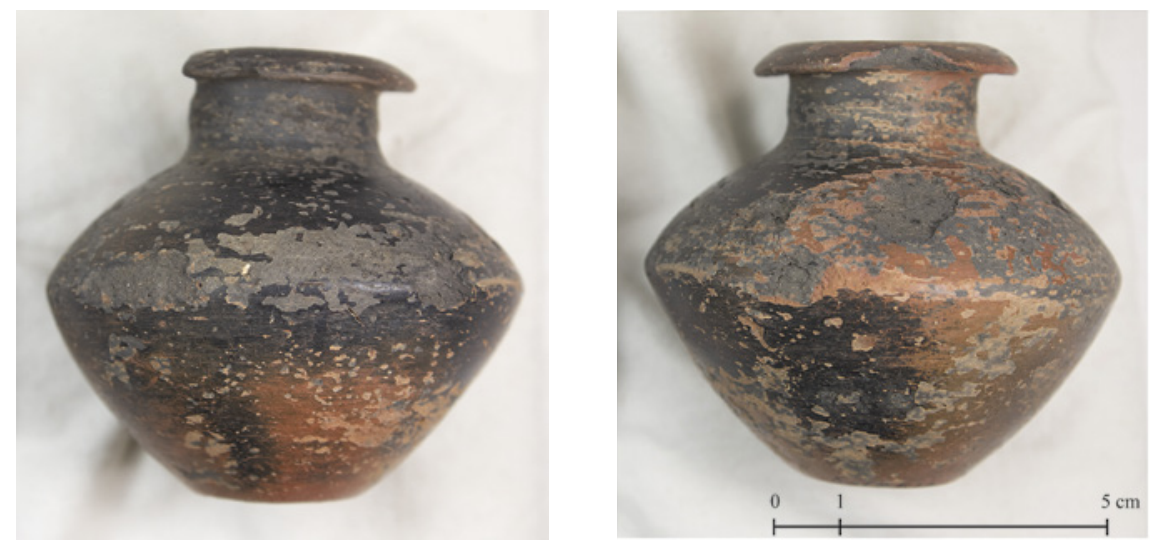

FIGURE 3.1A-B Carinated jar 6-12510 (N 2701)

\subsection{Vessel Description}

Produced in Nile B1 or a fine B2 fabric, ${ }^{6}$ this small jar was made in three parts: 1) rim and neck, 2) upper body, and 3) lower body. The latter two are connected at the carination. It is clear from the photos that the rim, neck, and upper body were turned. Inspection of the interior would be necessary to confirm a turned or handmade manufacturing technique for the lower body. A disc-shaped rim, formed by folding the rim downward, sits atop a narrow straight neck. The point of carination is above the midpoint of the body, and the lower body tapers down to a scraped flat base. A slip was added to the exterior surface and then well burnished. Narrow, tightly spaced horizontal burnishing strokes are visible. In some areas, the slip fired a light brown to reddish-brown color, but other areas are completely black. The most visually distinctive feature of this carinated jar is the black color of the surface and areas of dark gray or blackened fabric (visible because of damaged areas). Small jars with a black surface and fabric are sometimes said to be made of "black clay" and termed "black ware" or "black pottery." I will discuss the fabric and surface treatment separately, followed by two plausible explanations for the jar's blackened appearance.

"Black clay" is an incorrect description, and a black slip was not applied to the vessel. Regarding the fabric, the damaged areas on the jar make it possible

6 It is also necessary to distinguish between the natural clay source and the fabric. A pottery "fabric" is "a group designation for all significant physical and chemical properties of the clay and the non-plastic inclusions in a fired ceramic material, as well as all relevant technological features of the finished product" (Nordström and Bourriau 1993, 162).

7 For "black pottery" and "black ware," see Reisner 1932, 93. For "black ware," Slater 1974, 105. 
to see the fabric at different points on the body. A chip in the rim reveals a brown exterior zone, violet zone, and a thick black core. ${ }^{8}$ This is a typical Nile alluvial silt fabric. Most of the damage to the upper body, as visible in Fig. 3.1B, shows a very thin brown exterior zone and a thick black core. Areas where the slip has separated from the lower body show a mottled brown and black appearance to the fabric's exterior zone. Much of the damaged surface on the side of the jar reveals little to no brown exterior zone and a predominantly black colored fabric. The lower body shows a mottled brown and black fabric below the slip. The original color of the slip ranges from a light brown to reddish-brown and is most visible on the lower body and base. A large area of the rim, neck, and upper body (and to a lesser extent, the lower body) have a blackened surface.

I propose two plausible explanations for the black color of the surface and fabric.

1) The jar was fired in a reducing atmosphere. This means oxygen was not allowed to reach the pot during the firing process. The result is a black surface and fabric color. Firing pottery in a reducing atmosphere is a technique commonly found in Nubian pottery and Egyptian Predynastic black topped red ware, but it was also used for small Egyptian vessels in the late Old Kingdom through the early Middle Kingdom (see below).

2) The jar was burned post-firing, whether intentionally or unintentionally. The black color appears irregularly on the surface, and the amount of black color in the fabric varies at different points on the vessel. This could support burning of the vessel post-firing.

\subsection{Parallels and Discussion}

No other examples of reduced vessels from $\mathrm{N} 2000$ or $\mathrm{N} 2500$ are held in the Hearst collection or identifiable in the excavation negatives; however, there are additional examples from Naga ed-Deir of small carinated and bag-shaped jars fired in a reducing atmosphere. At the Hearst Museum, from Tomb $75^{2}$ in Cemetery 700 is a small bag-shaped jar (PAHMA 6-10755) with uneven reduced firing that reveals glimpses of the red-brown slip color on the body. ${ }^{9}$ Further

8 Gray or black "reduced" cores are common in Nile clay vessels. This is carbon that did not burn out during the firing process, which typically turns the gray Nile clay into a brown or reddish-brown color. The red hue is due to the high iron content in Egyptian Nile clay. Thick black cores are more common in vessels with thick walls, low fired vessels, and reduced vessels.

9 The jar at the Hearst Museum (https://webapps.cspace.berkeley.edu/pahma/imageserver/ blobs/7cdc2085-9a35-4aoo-963a/derivatives/OriginalJpeg/content) belongs to this type (Reisner 1932, 93, fig. 43:2). 
north at the cemeteries of Qau, Guy Brunton excavated similar examples of small black jars with differential reduced firing. One of these is a squat carinated jar at the Petrie Museum (UC18012). Most of the surface is black, but an area at the mid and lower body turned red and reddish-brown. ${ }^{10}$ It seems that either the firing technique(s) in the late Old Kingdom through the early Middle Kingdom could not consistently produce fully reduced vessels without oxygen reaching any part of the vessel (and thereby turning part of the slip red) or this was not deemed necessary.

Small jars fired in a reducing atmosphere have not received extensive study by modern or early scholars. Guy Brunton briefly acknowledged the peculiar pottery with black surfaces uncovered at Qau in late Old Kingdom and First Intermediate Period tombs: "Black pottery is only found in very rare cases, all being squat toilet vases. We found one in the vth, four in the vith, eight in the vii-viiith, and sixteen in the ix-xth dyns. In one case there was red wash on top of the black."11 The latter is probably referring to a carinated jar (Type $82 \mathrm{E}$ ) that was not fully reduced. ${ }^{12}$

Not all of these small jar types were reduced to create a black surface. The same vessel types also appear fully oxidized with the typical Egyptian red or reddish-brown slip. In fact, one of the closest parallels for the narrow neck of this jar from burial N 2701 at Naga ed-Deir is a fully oxidized jar from a First Intermediate Period cemetery at Dendera. ${ }^{13}$

It is difficult to be certain, but this small jar from Naga ed-Deir is a poorly executed example of an intentionally reduced vessel, or the current blackened areas are the result of a post-firing event that unevenly burned the jar.

\footnotetext{
10 This jar at the Petrie Museum (UC18o12) is Brunton's type $82 \mathrm{G}$ (Brunton 1928, pl. 87:82G).

11 Brunton 1928, 4. Some examples of small carinated jars termed as "Black," "Pol. Black," or "Black Pol." are on pl. 87:81C, 82A, pl. 91:85P, 81V, 81W.

12 Brunton 1928, pl. 91:82E (described as dark red polished on black).

13 Slater 1974, fig. 20:mih. Additionally, the best parallel for the shape of the carinated jar from N 2701 is a good example of the pitfalls of dating ceramics based on shape alone without consideration for key features in manufacturing technology and surface treatment, especially when relying on drawings. This "best parallel" is a carinated jar from Thebes in Dynasty 18 (Bader and Seco Álvarez 2016, 258, fig. 52:d, a small jar made in Marl A2 fabric with a red slip burnished horizontally on the rim and shoulders and burnished vertically below the carination). The key difference is in the method of production and surface treatment. The Naga ed-Deir jar was carefully burnished horizontally across the entire Nile clay vessel. The Thebes jar was burnished horizontally above the carination and vertically below the carination, turned more quickly on a wheel, and made of marl clay. Using shape alone can lead to incorrect dating.
} 


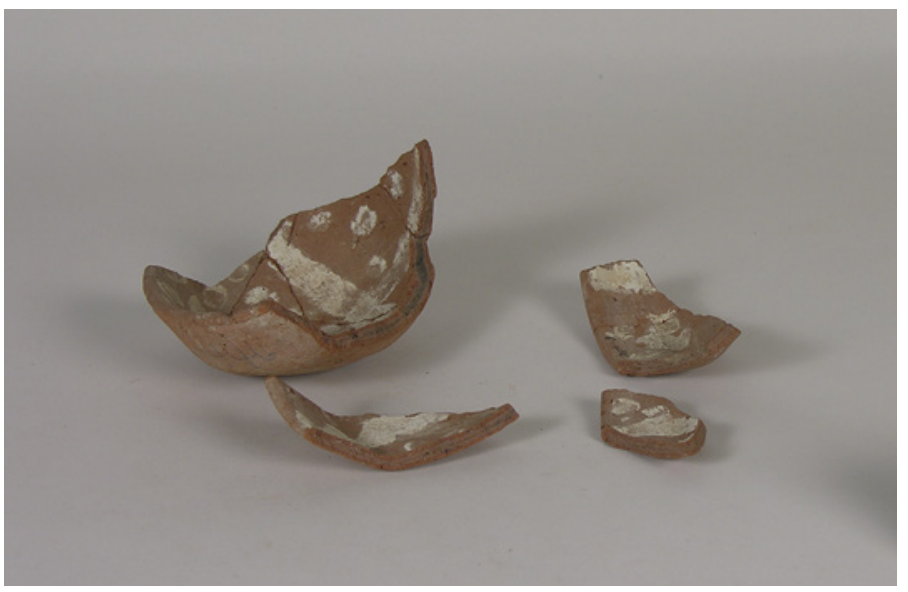

FIGURE 3.2 Carinated bowl 6-14507 (N 2446)

\subsection{Context}

A carinated bowl with white decoration of dots and two crossed lines (Figs. 3.2-3.3) was found in the main chamber of N $2446=\mathrm{N} 2522$ along with carinated bowls produced from the late First Intermediate Period up to early Dynasty $12,{ }^{14}$ a variety of bowls with simple contour known from the First Intermediate Period to early Dynasty $12,{ }^{15}$ small jars with quatrefoil rim from Dynasty $11,{ }^{16}$ early/pre-hes-jars produced from the First Intermediate Period to early Dynasty $12,{ }^{17}$ First Intermediate Period shouldered jars with modeled

14 Carinated bowls pahma 6-14477; ранма 6-14501. See Schiestl and Seiler 2012, 230. Carinated bowl ring base PAHмA 6-14526.

15 Bowls with simple contour, direct or modeled rims, and round bases PAHMA 6-14473-

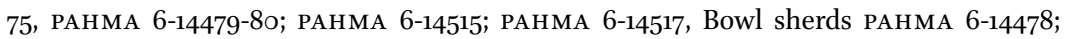
PAHMA 6-14484; PAHMA 6-14486; PAHMA 6-14494. For parallels to PAHMA 6-14473-75, see Wodzińska 2010, 162, First Intermediate Period 36.

16 Small jars with quatrefoil rims and flat/nearly flat bases РАHMA 6-14499; РАHMA 6-1450O; PAHMA 6-14504; PAHMA 6-14508; PAHMA 6-14523; PAHMA 6-14528 and round bases PAHMA 6-145022. See Schiestl and Seiler 2012, 388.

17 hes-jars PAнma 6-14487; PAнмa 6-14512; PAнma 6-14525; PAнma 6-14529. See Schiestl and Seiler 2012, 508, 512. The type of pre-hes-jar with no splayed base disappears after early Dynasty 12 and was only used in cemeteries (Arnold 1972, Abb. 5:12). 


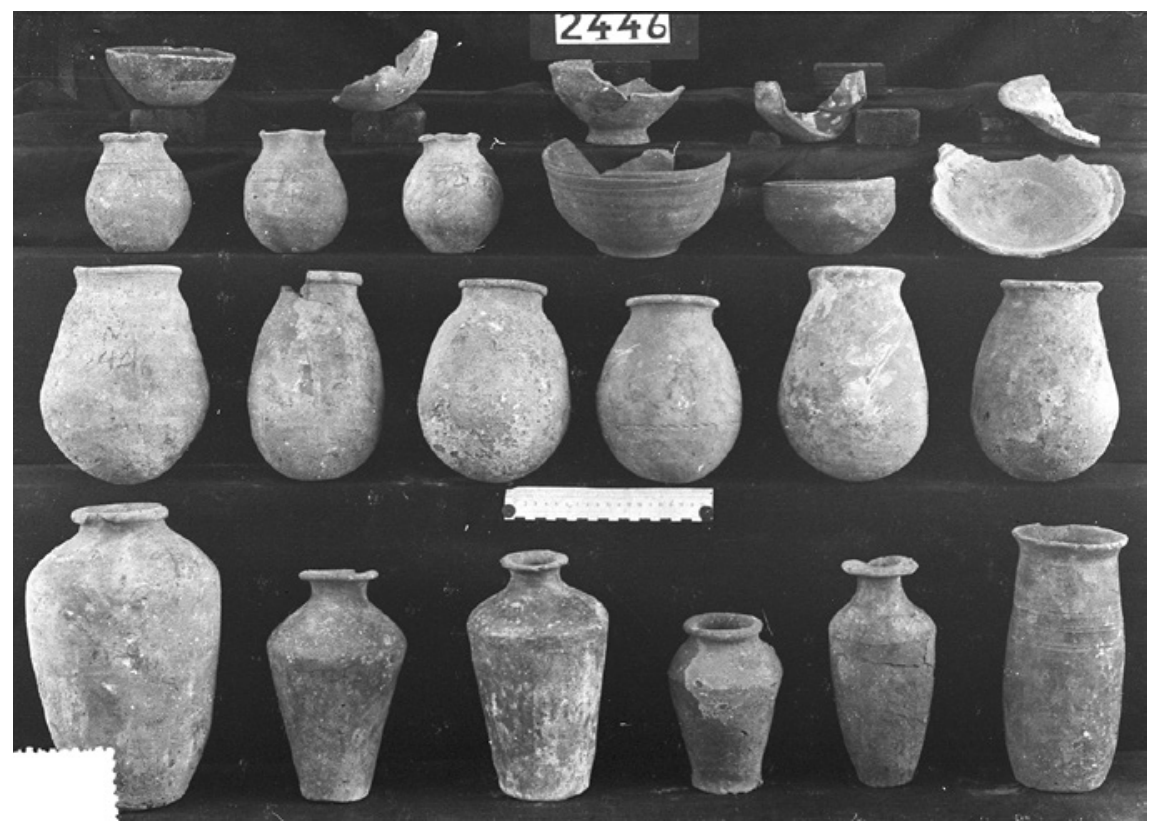

FIGURE 3.3 Ceramics of N 2446; top row \# 4 is 6-14507 (NED-B-7142)

rim, ${ }^{18}$ bag-shaped jars with modeled rim found from early Dynasty 11 to early Dynasty $12,{ }^{19}$ a tall stand, ${ }^{20}$ a few "glaze" beads, and a "disc." ${ }^{21}$

\subsection{Vessel Description}

The Naga ed-Deir bowl is turned with a carination near the midpoint of the body. An incised line runs below the direct rim, the upper body has straight sides, and the lower body tapers to a scraped flat base. Nile B2 fabric was used

18 Jars with modeled rim, narrow neck, prominent shoulder, and flat base PAHMA 6-14488; PAHMA 6-14503. These jars have more resemblance to the late Old Kingdom tradition than the early Middle Kingdom tradition.

19 Small to medium jars with modeled rims and round scraped bases PAHMA 6-14481; PAHMA 6-14483; PAHMA 6-14489-91; PAHMA 6-14495-98; PAHMA 6-14502; PAHMA 6-14505o6; PAHMA 6-14510-11; PAHMA 6-14513-14; PAHMA 6-14516; PAHMA 6-14518-21; PAHMA 614527; PAHMA 6-14530-32; PAHMA 6-14534-36, jar sherds PAHMA 6-14476; PAHMA 6-14485; ранма 6-14492-93; PAнма 6-14509; PAнмa 6-14524. See Schiestl and Seiler 2012, 536; Arnold 1972, Abb. 3:7.

20 Tall stands PAHMA 6-14482; PAHMA 6-14533.

21 It is necessary to bear in mind that pottery traditions do not change according to dynastic succession. For example, late Dynasty 11 and early Dynasty 12 is the same pottery phase. Other material culture or textual evidence is needed to assign an assemblage to either late Dynasty 11 or early Dynasty 12 . 
to make the bowl, and a thin red slip covers the body. White paint was used to apply decoration over the red slip. ${ }^{22}$ Two white bands of irregular widths run from one side of the rim to the other, crossing each other in the center of the bowl, and dividing the interior surface into four quadrants. These quadrants are decorated with white dots applied with the fingertips. The denuded appearance of some areas of the decoration is due in part to the paint being applied post-firing and, therefore, being more fragile and easily scraped off the surface.

\subsection{Parallels and Discussion}

Concerning the shape of the carinated bowl from N $2446=\mathrm{N} 2522$, it is a welldocumented type that first appears in Upper Egypt in late Dynasty 11 and spreads across Egypt in early Dynasty $12 .{ }^{23}$ What distinguishes this bowl from other examples of this type is the white painted decoration.

Vessels with white painted decoration of lines and/or dots first appear in the First Intermediate Period, are rarer in the Middle Kingdom, and appear with more frequency in the Second Intermediate Period and early Dynasty 18. Vessel function can be difficult to confidently pinpoint, but Schiestl and Seiler do ascribe a ritual or funerary purpose to the type. ${ }^{24}$ Bowls are the most common shape with this decoration; however, the use of white painted decoration is not uniform throughout Egypt or across different periods. For example, Assiut is a site with a well-documented development of vessels with white painted decoration, with the highest frequency of examples in the First Intermediate Period. ${ }^{25}$ Hemispherical bowls, carinated bowls, and small jars are found with this decoration. ${ }^{26}$ Interestingly, the combination of the crossed lines and dots motif found on the Naga ed-Deir bowl is not found on the Assiut bowls in the First Intermediate Period. Fewer examples and varieties of decorated shapes are found at Middle Kingdom Assiut. ${ }^{27}$ At Abydos, bowls with simple contour and flat base were decorated with white dots irregularly applied on the interior

22 The white paint could be lime based. Examples have been tested elsewhere (e.g., Thebes). See Bader and Seco Álvarez 2016, 211.

23 Schiestl and Seiler 2012, 236.

24 Schiestl and Seiler 2012, 182, 184, figs. 2-3. See the bibliography on p. 182 for further sites with examples of bowls with simple contour, flat base, and painted decoration.

25 Rzeuska 2017, 179-186.

26 Rzeuska 2017, 180, 186, Tab. 2; jars Cat. 155-167; hemispherical bowls Cat. 168-171, 174; carinated bowls Cat. $172-173$.

27 Rzeuska 2017, 180, 303-307, Tab. 3, Cat. 290-306. Examples in the Second Intermediate Period are rare and restricted to one vessel type (Rzeuska 2017, 180, 421-422, Cat. 328-329). 
and a white band at the rim. ${ }^{28}$ Bowls with flat bases and decoration of white crossed lines and dots were excavated in a settlement context at Dendera. They are rare, and Sylvie Marchand dates these examples to the end of Dynasty $11 .{ }^{29}$

Bowl PAHMA 6-14507 is not the only example of white painted decoration on pottery from the Naga ed-Deir cemeteries. Two additional bowls appear in an excavation photo (NED-A-7673, top row, third from right; NED-A-7673, second row, sixth from right $=$ Fig. 2.29). The precise context of these bowls is not clear, and their current location is unknown. All three bowls differ from one another in shape, but the interior decoration is the same pattern of two crossed lines and dots. The largest bowl (NED-A-7673, top row, third from right = Fig. 2.29) has a direct rim, simple contour, and most probably a flat base. The rim exhibits a wide white band with two white crossed lines on the interior and irregularly spaced white dots in the space between the lines. The third bowl with white painted decoration is a hemispherical bowl with the same pattern of irregularly spaced dots and white crossed lines on the interior. There is no white rim band and, surprisingly, there are white dots irregularly spaced on the exterior of the bowl. Presently, this is the only example of a bowl with white spots on the exterior known to me.

Although not comprising a large percentage of any cemetery or settlement context in Egypt, bowls decorated with white lines and/or dots are known from several sites with First Intermediate Period through early Middle Kingdom contexts. The three bowls with white painted decoration from Naga ed-Deir incorporate the site into this wider phenomenon.

РАНМА 6-14428, РАНMA 6-14429, РАНMA 6-2799 Offering Stand with Incised Decoration

\subsection{Context}

A heavily disturbed burial, $\mathrm{N}$ 2099, retained an offering stand with incised decoration (Fig. 3.4; also, Fig. 2.28, bottom row, second from right, and NED-B-7146 [unpublished]), early Dynasty 11 to early Dynasty 12 bag-shaped jars, ${ }^{30}$ early/ pre hes-jars known from Dynasty 11 to early Dynasty $12,{ }^{31}$ early forms of the

28 Steinman 1998, Tafel 92:5-6, Kat.-Nr. 320. In the Second Intermediate Period, jars with white rim and white dots decorating the shoulder were found at the site (Steinman 1998, Tafel 95:2, Kat.-Nr. 333).

29 Marchand 2012, 281, note 44, fig. 16, Group 8 (Phase 3b); Marchand 2004, 220, figs. 51-52 (end of Phase 3).

$30 \quad$ Schiestl and Seiler 2012, 536; Arnold 1972, Abb. 3:7.

31 Schiestl and Seiler 2012, 512; Arnold 1972, Abb. 5:12. 

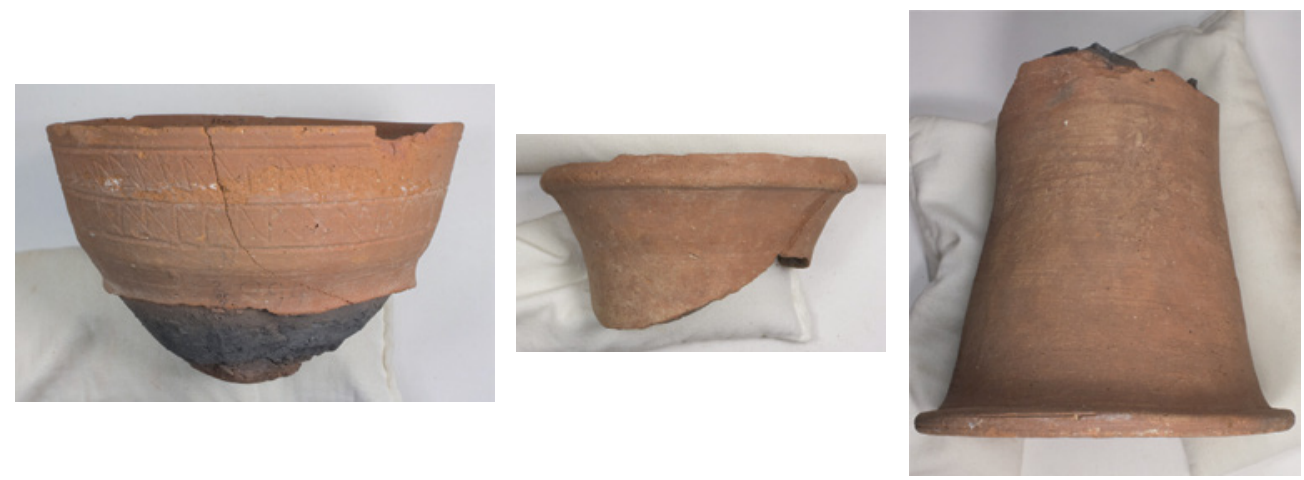

FIGURE 3.4A-C Offering stand 6-14428, 6-2799, 6-14429 (N 2099)

hes-jar with splayed base that first appears around mid-Dynasty $11,{ }^{32}$ hemispherical bowls, ${ }^{33} 4$ small "saucers," ${ }^{34}$ and pieces of charcoal. The offering stand, jars, and hes-jars are visible in situ at the entrance to the tomb in a field photograph (Fig. 3.5).

\subsection{Vessel Description}

The offering stand's unusual appearance is the result of joining a carinated bowl and a stand before they were fired. The stand has a modeled rounded rim that is not flush where it joins with the bowl. This is atypical for an offering stand. It appears that a carinated bowl was turned separately and then fitted into the top of a fully formed stand in the leather-hard stage pre-firing. This method of joining two separate pieces was not a complete success, as the bowl separated from the stand in antiquity. In the photo of the offering stand still in situ (Fig. 3.5), a crack is visible where the bowl and stand were joined by the potter. ${ }^{35}$

Both the bowl and stand were made in Nile B1 or a fine Nile B2 fabric with a red slip on the exterior surfaces, as well as on the interior of the bowl. This carinated bowl with direct rim was turned, while the stand was formed with a combination of coiling and turning. ${ }^{36}$ The body above the carination on the

$32 \quad$ Schiestl and Seiler 2012, 508, 512.

33 Hemispherical bowl with direct rim PAнма 6-14428.

$34 \quad$ No further description given for the saucers.

35 The full shape, as well as the crack, is more visible in NED-B-7146 and NED-A-756o (Fig. 2.28).

36 Partially smoothed coils of clay are visible on the interior surface near the top of PAHMA 6-14429. 


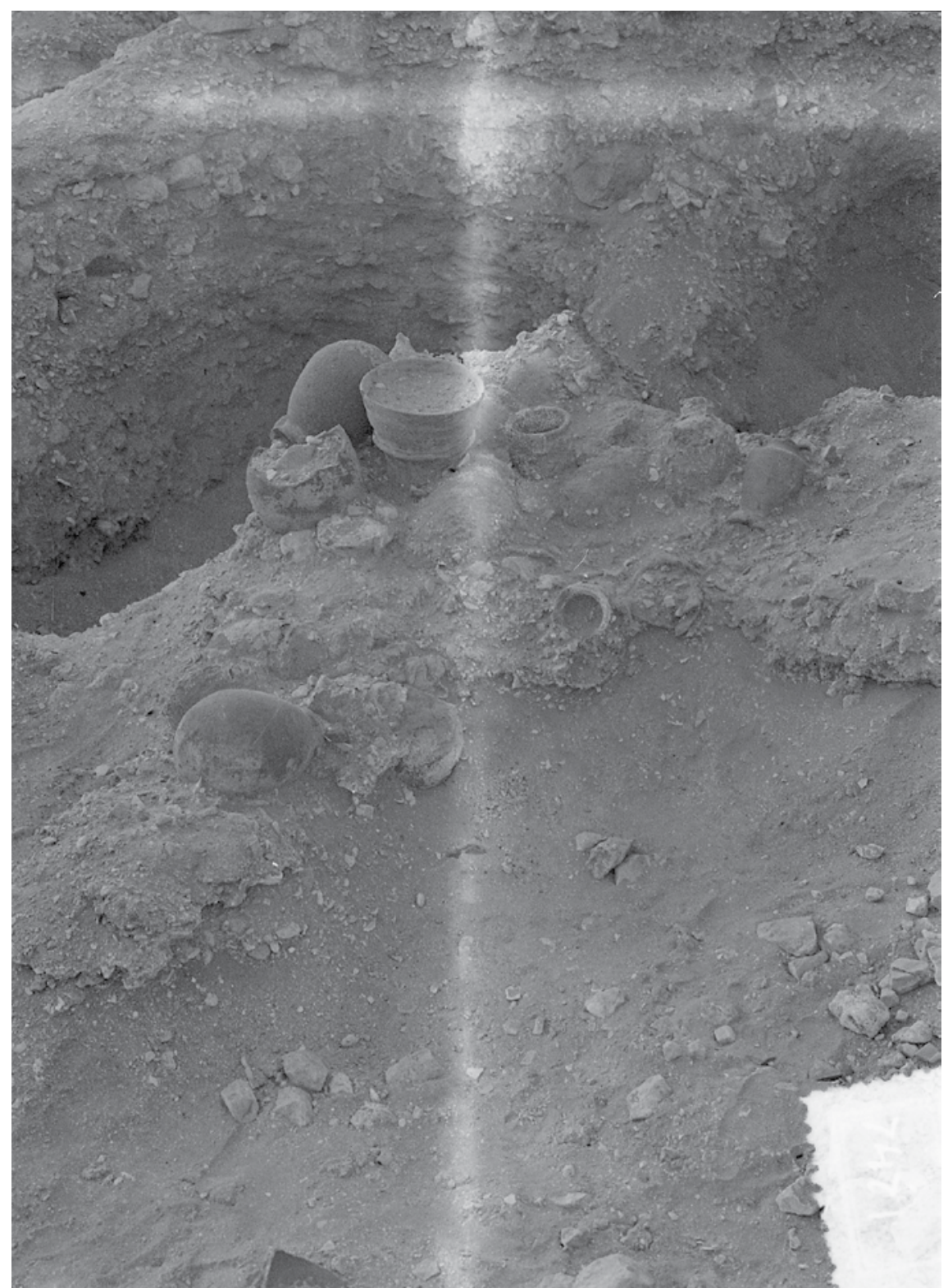

FIGURE 3.5 Ceramics in position N 2099 (NED-B-7471) 
bowl shows incised decoration. Two rows of wavy lines are separated by and bounded by horizontal lines. A small area between the carination and the start of the stand was scraped horizontally. The stand column ends with a modeled everted base.

\subsection{Parallels and Discussion}

The Naga ed-Deir offering stand is unusual because the potter appears to have joined a fully formed stand to a bowl without making the join flush and also because the offering stand has incised decoration. ${ }^{37}$ Since this combination is unusual and possibly unique, the best sources for comparanda are carinated bowls with direct rim, ring base, and complex incised decoration. These bowls have a long chronological span in Egyptian cemetery and settlement contexts. They first appear in Upper Egypt in late Dynasty 11 or early Dynasty $12 .{ }^{38}$ In the Qau to Matmar region, carinated bowls with alternating bands of wavy and horizontal lines are found in cemetery contexts of mid to late Dynasty 11 and early Dynasty 12 (Stufe Iпв). ${ }^{39}$ This is also the pottery phase when carinated bowls with a ring base and incised decoration are first found at Elephantine. ${ }^{40}$ Marchand calls the carinated bowls with two rows of wavy lines, like what is found on the Naga ed-Deir offering stand, a hallmarker for Phase 3 (end of First Intermediate Period-Dynasty 11) at Dendera. ${ }^{41}$ Much further to the north at Tell el-Daba, numerous carinated bowls with alternating rows of wavy and straight lines incised on the upper body have been found. The long development of the type at Tell el-Daba begins in early Dynasty $12 .{ }^{42}$

Three additional large carinated bowls with incised decoration were photographed during the excavation at Naga ed-Deir. All three have ring bases and were not attached to stands. Two of the bowls exhibit two horizontal lines incised below the rim and a band of wavy lines incised on the upper body (Fig. 2.29, second row from bottom, second from right, and NED-C-8546, top row, first from right [unpublished]), while the third example is incised with

$37 \quad$ I am unaware of any published examples of an offering stand made with this technique and with incised decoration.

38 Schiestl and Seiler $(2012,224)$ place the first carinated bowls with ring bases and incised wavy lines in early Dynasty 12. Marchand dates examples at Dendera earlier (Phase 3, end of First Intermediate Period-Dynasty 11).

39 Seidlmayer 1990, 152, Abb. 59:K-Ao6.o2.

40 Seidlmayer 1990, 434, Abb. 176.

41 Marchand 2004, 220, figs. 44-46.

42 Czerny 2015, Abb. T49-5o, 294, Abb. T51 for development of the type. 

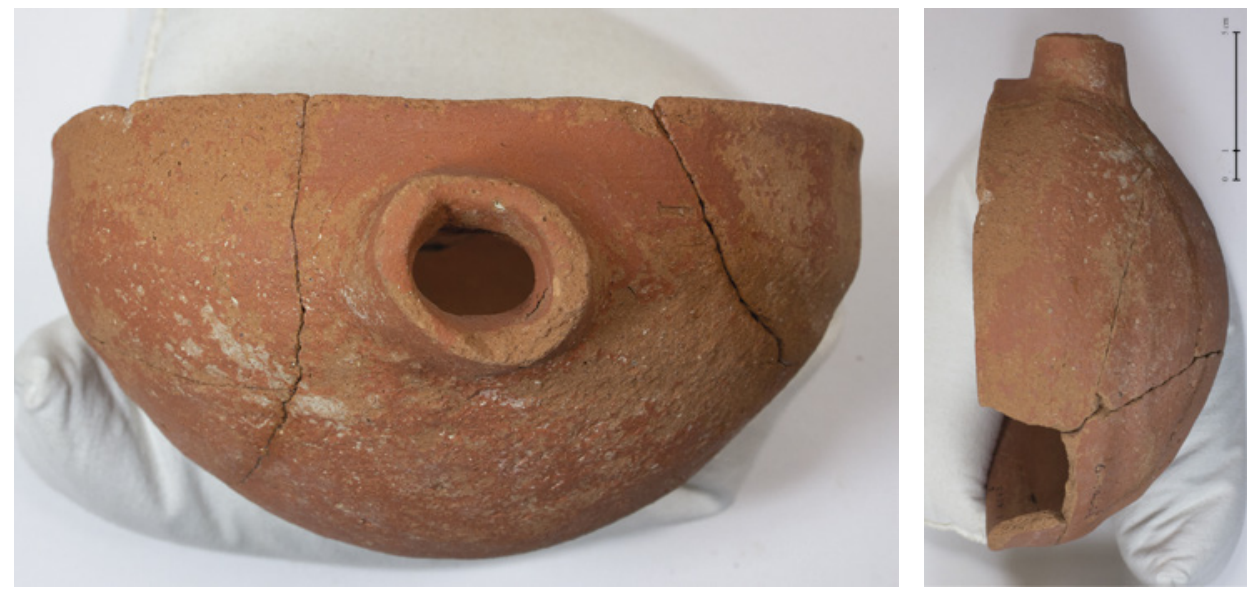

FIGURE 3.6A-B Carinated bowl with spout 6-14542.1 (N 2490)

alternating rows of straight and wavy lines on the entire upper body (NED-B7110, top row, second from left [unpublished]; N 3568).

Carinated bowls with incised decoration have a long chronological history and wide geographical spread across ancient Egypt; however, the combination of an incised carinated bowl with a fully formed stand shows a creative take on the offering stand at Naga ed-Deir.

PAHMA 6-14542.1 Carinated Bowl with Spout

\subsection{Context}

This spouted bowl was found in situ at the entrance to the pit of N 2490 still sitting on a tall stand (PAHMA 6-14542.2) with a "double base" similar to those found in the First Intermediate Period at Assiut (Figs. 2.5, 2.28, 2.33; NED-B7467 [unpublished]). ${ }^{43}$ Several bag-shaped jars with modeled rim characteristic of Dynasty 11 to early Dynasty 12 were also found in this deposit. ${ }^{44}$

43 Double rims and double bases have a shallow incised horizontal line that gives the rim or base a double or stacked appearance. See Rzeuska 2017, 159, fig. 106, Cat. 102.

44 See image NED-C-7158 (Fig. 2.33). At least eight round base jars with modeled rim are visible and appear to be part of the same deposit. The bowl (NED-B-7146, top row, first from right) is possibly a deep inflected bowl, which is a type produced from the First Intermediate Period until the reign of Senwosret II (Schiestl and Seiler 2012, 208). 


\subsection{Vessel Description}

This bowl was made in three parts: 1) rim and upper body, 2) lower body, and 3) spout. From the slightly everted rim down to the subtle carination, the bowl was turned. The exterior surface of the lower body and round base shows a rippled appearance, which could be the result of a handmade forming technique. ${ }^{45}$ A large handmade spout was attached to one side below the rim area. The fabric employed is Nile $\mathrm{B} 1$, and a red slip covers all exterior and interior surfaces including inside the spout.

\subsection{Parallels and Discussion}

Spouted bowls have a long history in the Egyptian pottery corpus. Although not characteristically appearing in high numbers, spouts are found attached to bowls, jars, ewers, deep vats, and miniature vessels. Bowls with attached spouts are known from settlement and funerary contexts and were used for short-term storage and pouring liquids. ${ }^{46}$ The Naga ed-Deir shallow spouted bowl with rounded base is not a common type in this period. ${ }^{47}$ Spouted vats with modeled rim and flat base are more common in the First Intermediate Period up to early Dynasty 12 and mostly used for food and beer production in settlements. ${ }^{48}$ A spouted bowl of similar shape to Naga ed-Deir PAHMA 6-14542.1 was discovered at Assiut. ${ }^{49}$ Additional spouted bowls from Naga ed-Deir are in the photos from Reisner's excavation, but these bowls belong to the late Old Kingdom in shape and technology. 50

\section{$5 \quad$ Conclusions}

The majority of the pottery from Naga ed-Deir cemeteries N 2000 and N 2500 are part of a standard repertoire of types known elsewhere in Egypt from the First Intermediate Period through early Dynasty 12 and are found in multiples in these cemeteries. The four vessels briefly presented in this chapter show the

45 Without seeing the bowl in person, it is difficult to determine if the lower body and base are handmade or turned and the resulting rippled appearance is due to a smoothing technique/tool.

46 Schiestl and Seiler 2012, 342.

47 There are no parallels in Schiestl and Seiler for this period.

48 Schiestl and Seiler 2012, 730; Slater 1974, 64-65, fig. 12:C7c.

49 Rzeuska 2017, 306, fig. 247, Cat. 306. This completely turned bowl with a spout is from a Middle Kingdom context and later than the Naga ed-Deir bowl.

50 See image NED-B-7145, top row, first and second from left and Wodzińska 2010, 135, Old Kingdom 40. 
addition of rare or unique elements, while still finding points of connection with wider trends outside of Naga ed-Deir.

\section{Bibliography}

Arnold, D. 1972. "Weiteres zur Keramik von el-Târif. Saff el-Dawâba 1970/71." MDAIK 28: 33-46.

Bader, B. and M. Seco Álvarez. 2016. "Results of Five Years of Pottery Analysis in the Temple of Millions of Years of Thutmosis III in Western Thebes (2011-2015)." Ägypten und Levante 26:157-262.

Brunton, G. 1928. Qau and Badari II. London.

Czerny, E. 2015. Tell el-Dab'a XII. "Der Mund der beiden Wege": Die Siedlung und der Tempelbezirk des Mittleren Reiches von Ezbet Ruschdi, edited by M. Bietak. Vienna.

Marchand, S. 2004. "Fouilles récentes dans la zone urbaine de Dendara: la céramique de la fin de l'Ancien Empire au début de la XII e dynastie." CCE 7: 211-238.

Marchand, S. 2012. "Dendara." In Handbook of Pottery of the Egyptian Middle Kingdom, Volume 2: The Regional Volume, edited by R. Schiestl and A. Seiler. Vienna.

Nordström, H.-Å. and J. Bourriau. 1993. "Ceramic Technology: Clays and Fabrics. Fascicle 2." In An Introduction to Ancient Egyptian Pottery, edited by Do. Arnold and J. Bourriau, 142-19o. Mainz.

Reisner, G. A. 1932. A Provincial Cemetery of the Pyramid Age. Naga-ed-Dêr. Part III. University of California Publications, Egyptian Archaeology 6. Berkeley.

Rzeuska, T. I. 2017. Chronological Overview of Pottery from Asyut. A contribution to the history of Gebel Asyut al-gharbi. Wiesbaden.

Schiestl, R. and A. Seiler. 2012. Handbook of Pottery of the Egyptian Middle Kingdom, Volume I: The Corpus Volume. Vienna.

Seidlmayer, S. J. 199o. Gräberfelder aus dem Übergang vom Alten zum Mittleren Reich. Studien zur Archäologie der Ersten Zwischenzeit. Heidelberg.

Slater, R. A. 1974. The Archaeology of Dendereh in the First Intermediate Period. PhD thesis. University of Pennsylvania.

Steinman, F. 1998. Tongefässe von der Vordynastischen Zeit bis zum Ende des Mittleren Reiches. Mainz.

Wodzińska, A. 2010. A Manual of Egyptian Pottery. Volume 2: Naqada III-Middle Kingdom. Revised First Edition. Boston. 